\title{
PENGARUH PEMBERIAN JUS BUAH NAGA MERAH (Hylocereus polyrhizus) TERHADAP PENURUNAN TEKANAN DARAH
}

\section{The Influence of Giving Red Dragon Fruit Juice (Hylocereus polyrhizus) to Decrease Blood Pressure}

\author{
Finda Khoirun Nisa ${ }^{1}$, Farida Wahyu Ningtyias ${ }^{*}{ }^{1}$, Sulistiyani ${ }^{1}$ \\ ${ }^{1 .}$ Fakultas Kesehatan Masyarakat, Universitas Jember, Indonesia
}

Diterima: 08 Mei 2019; Revisi: 15 Juli 2019; Diterbitkan: 29 Juli 2019

\section{Abstract}

Background: Hypertension is a health problem that needs to be considered because of the high prevalence rate. Red dragon fruit (Hylocereus polyrhizus) contains potassium, flavonoids and vitamin $\mathrm{C}$ that can lower blood pressure. Dragon fruit's peel contained pentacyclic, triyepene, and taraxast to deflect the blood vessel. Objective: This study aimed to prove the influence of giving red dragon fruit juice with the addition of the red dragon fruit's peel as much as 20\% against a decrease in blood pressure. Design: This type of research was quacy experimental with non-equivalent control group design. This study used 36 subjects aged 18-40 years, with optimal, normal and normal high blood pressure. The subjects of the research were divided into a control group and treatment group. The treatment group was given the red dragon fruit juice as much as $200 \mathrm{ml}$ that taken from 100 grams of red dragon fruit and red dragon fruit's peel as much as $20 \%$ is given twice a day for 3 days.Control group was not given the treatment, only was controlled pretest and posttest blood pressure. Analysed of the statistics used Independent t-test, Mann-Whitney, Dependent t-test and Wilcoxon. . Results: The treatment group experienced a reduction in systolic and diastolic blood pressure by 6.11 $\pm 6.31 \mathrm{mmHg}(\mathrm{p}=0.002)$ and $3.33 \pm 4.53 \mathrm{mmHg}(\mathrm{p}=0.189)$. Conclusion: The influence of giving red dragon fruit juice with the addition of red dragon fruit's peel as much as $20 \%$ is effective to decrease systolic blood pressure

Keywords: Blood pressure, Red dragon fruit, Red dragon fruit's peel

\section{Abstrak}

Latar Belakang: Hipertensi merupakan masalah kesehatan yang perlu diperhatikan karena angka prevalensinya yang tinggi. Buah naga merah (Hylocereus polyrhizus) mengandung kalium, flavonoid, dan vitamin $\mathrm{C}$ yang dapat menurunkan tekanan darah. Kulit buah naga mengandung zat pentacyclic, triyepene, dan taraxast yang dapat melenturkan pembuluh darah. Tujuan: Penelitian ini bertujuan membuktikan pengaruh pemberian jus buah naga merah dengan penambahan kulit buah naga merah sebanyak 20\% terhadap penurunan tekanan darah. Metode: Jenis penelitian ini adalah quacy experimental dengan rancangan non equivalent control group design. Penelitian ini menggunakan 36 subjek berusia 18-40 tahun, dengan tekanan darah optimal, normal, dan normal tinggi. Subjek penelitian kemudian dibagi menjadi kelompok perlakuan dan kelompok kontrol. Kelompok perlakuan diberi jus buah naga merah sebanyak $200 \mathrm{ml}$ yang berasal dari 100 gram daging buah naga merah dan kulit buah naga merah sebanyak $20 \%$ yang diberikan 2 kali sehari selama 3 hari. Pada kelompok kontrol tidak diberi perlakuan, hanya dilakukan kontrol tekanan darah pretest dan posttest.Analisis statisitik menggunakan uji Independent t-test, Mann-Whitney, Dependent t-test dan Wilcoxon. Hasil: Kelompok perlakuan mengalami penurunan tekanan darah sistolik dan diastolik sebesar $6,11 \pm 6,31 \mathrm{mmHg}$ $(\mathrm{p}=0,002)$ dan $3,33 \pm 4,53 \mathrm{mmHg}(\mathrm{p}=0,189)$. Kesimpulan: Pemberian jus buah naga merah dengan penambahan kulit buah naga merah sebanyak $20 \%$ efektif dalam menurunkan tekanan darah sistolik.

Kata Kunci: Remaja putri, konsumsi makanan, status gizi, aktivitas fisik, PMS

*Korespondensi: Farida Wahyu Ningtyias, Email : farida.fkm@unej.ac.id

DOI : $10.22487 / \mathrm{j} 26227622.2019 . v 3.11 .12667$

\section{PENDAHULUAN}

Hipertensi adalah suatu keadaan ketika tekanan darah di pembuluh darah meningkat secara kronis. Jika dibiarkan, penyakit ini dapat mengganggu fungsi organ-organ lain, terutama organ-organ vital seperti jantung dan ginjal.Secara nasional, terjadi peningkatan prevalensi hipertensi di Indonesia berdasarkan wawancara, yaitu dari 7,6\% pada tahun 2007 menjadi
9,5\% pada tahun 2013(Kementerian Kesehatan RI, 2013). Total angka kejadian hipertensi di Kabupaten Jember pada tahun 2015 adalah sebanyak $73.876 \mathrm{ka}-$ sus. Berdasarkan data dari Dinas Kesehatan Kabupaten Jember, tren peningkatan jumlah penderita hipertensi tahun 2015 terbanyak adalah di Puskesmas Kaliwates Kabupaten Jember, yaitu terjadi peningkatan jumlah penderita hipertensi dari 236 kasus pada tahun 2014 
menjadi 949 kasus pada tahun 2015(Dinas Kesehatan Kabupaten Jember, 2015).

Penatalaksanaan hipertensi terdiri dari terapi non farmakologis dan terapi farmakologis. Modifikasi pola asupan makanan sehari-hari merupakan salah satu komponen terapi non farmakologis yang mempunyai peran paling besar dalam menurunkan tekanan darah (Kumala, 2014). Terapi pengobatan memerlukan kepatuhan yang tinggi dan aspek biaya merupakan faktor yang berpengaruh terhadap kelangsungan proses terapi. Untuk itu diperlukan alternatif pada asupan makanan untuk membantu menurunkan tekanan darah. Kabupaten Jember memiliki komoditi buah andalan yang memiliki peluang sebagai alternatif untuk membantu menurunkan tekanan darah, yaitu buah naga merah.

Buah naga merah mengandung kalium dan flavonoid yang tinggi sehingga dapat menurunkan tekanan darah(Siswoyo, 2013). Selain itu, buah naga merah sangat kaya akan vitamin $\mathrm{C}$. Vitamin $\mathrm{C}$ yang terkandung dalam daging buah naga merah sangat mencukupi kebutuhan perhari individu yaitu mencapai $540,27 \mathrm{mg} / 100$ g(Norhayati, 2006). Konsumsi buah naga merah biasanya hanya memanfaatkan buahnya saja, sedangkan limbah kulitnya yang berjumlah 30$35 \%$ berat buah kurang termanfaatkan. Kulit buah naga dipercaya mengandung zat pentacyclic, triyepene, dan taraxast yang dapat melenturkan pembuluh darah (Handayani, 2014). Berdasarkan latar belakang tersebut maka peneliti tertarik untuk menganalisis pengaruh pemberian jus buah naga merah (Hylocereus polyrhi$z u s$ ) dengan penambahan kulit buah naga merah sebanyak $20 \%$ terhadap penurunan tekanan darah di wilayah kerja Puskesmas Kaliwates Kabupaten Jember

\section{BAHAN DAN METODE}

Penelitian ini merupakan penelitian quacy experimental dengan memberikan perlakuan pada subjek penelitian. Desain penelitian adalah non equivalent control group design denganpemberian secara single blind. Populasi dalam penelitian ini adalah usia dewasa muda yang tinggal di Kelurahan Tegal Besar Kecamatan Kaliwates Kabupaten Jember. Kriteria inklusi dalam penelitian ini adalah tinggal di Kelurahan Tegal Besar Kecamatan Kaliwates Kabupaten Jember, memiliki tekanan darah optimal, normal, dan normal tinggi, serta berusia 18-40 tahun. Kriteria eksklusi adalah tidak bersedia menjadi subyek penelitian, mengalami diare dan/atau hipotensi, subjek penelitian merasa tidak nyaman dengan pemberian perlakuan dan ingin undur diri dari penelitian, serta subjek penelitian mengalami hipertensi.

Teknik pengambilan sampel dalam penelitian ini menggunakan non probability sampling metode purposive sampling. Teknik perhitungan sampel menggunakan rumus Federer: (t-1) $(\mathrm{r}-1) \geq 15$ dan koreksi dengan 1/(1-f) untuk mengantisipasi hilangnya unit eksperimen, sehingga didapatkan jumlah sampel sebanyak 36.

Kelompok penelitian terdiri dari kelompok perlakuan dan kelompok kontrol. Masing-masing kelompok terdiri dari 18 subjek penelitian. Kemudian dilakukan pretest dengan mengukur tekanan darah sistolik dan diastolik sebagai data awal sebelum perlakuan. Pada kelompok perlakuan diberikanintervensi berupa jus buah naga merah
(Hylocereus polyrhizus) sebanyak $200 \mathrm{ml}$ yang berasal dari 100 gram daging buah naga merah dan kulit buah naga merah sebanyak $20 \%$ yang diberikan 2 kali per hari $(2 \times 200 \mathrm{ml})$ selama 3 hari.

Pengukuran tekanan darah sistolik dan diastolik posttest dilakukan setiap hari setelah dua jam pemberian jus frekuensi ke-2, untuk mengetahui apakah ada perbedaan rata-rata tekanan darah sebelum dan sesudah perlakuan. Pada kelompok kontrol tidak diberi jus buah naga merah, hanya dilakukan kontrol tekanan darah pretest dan posttest. Satu jam sebelum melakukan pengukuran tekanan darah pre test maupun post test, subjek penelitian dianjurkan agar tidak mengonsumsi teh, kopi, dan tidak banyak beraktivitas.

Prosedur pemberian jus buah naga merah (Hylocereus polyrhizus) dilakukan dengan memberikan jus yang telah dipersiapkan oleh peneliti. Jus buah naga merah frekuensi pertama diberikan di antara dua waktu makan (di antara waktu sarapan dan makan siang), yaitu pada jam 9 pagi, sedangkan jus buah naga merah frekuensi kedua diberikan di antara dua waktu makan (di antara waktu makan siang dan makan malam), yaitu pada jam 3 sore. Pengukuran tekanan darah sistolik dan diastolik pre test dilakukan pada hari pertama penelitian sekitar jam 8 pagi. Pengukuran tekanan darah pre test bertujuan untuk mendapatkan tekanan darah awal sebelum dilakukan pemberian perlakuan.Pengukuran tekanan darah post test dilakukan pada hari pertama sampai pada hari ke-3, yaitu sekitar 2 jam setelah pemberian perlakuan frekuensi kedua sekitar jam 5 sore.

Variabel karakteristik subjek penelitian adalah usia dan jenis kelamin. Variabel pengganggu meliputi asupan lemak, kalium, kalsium, magnesium, vitamin c, natrium dan serat yang diperoleh dengan metode food recall $3 \times 24$ jam dan diolah dengan program nutrisurvey dan Tabel Komposisi Pangan Indonesia (TKPI) tahun 2009. Data tekanan darah sistolik dan diastolik diperoleh melalui pengukuran tekanan darah yang dilakukan oleh tenaga kesehatan (bidan).

Analisis data secara statistik dilakukan menggunakan software SPSS (Statistical Product and Service Solutions). Uji normalitas menggunakan Shapiro Wilk. Untuk mengetahui perbedaan rata-rata tekanan darah sebelum dan sesudah perlakuan menggunakan uji Wilcoxon. Sedangkan untuk mengetahui perbedaan penurunan tekanan darah antara kelompok perlakuan dan kelompok kontrol sesudah perlakuan menggunakan uji Mann Whitney $(\alpha=0,05)$.

\section{Keterbatasan Penelitian}

Penelitian ini memiliki keterbatasan, yaitu pengambilan subjek dilakukan secara nonrandom. Pembagian kelompok penelitian dilakukan berdasarkan kesediaan subjek untuk berpartisipasi dalam penelitian. Hanya subjek yang bersedia mengkonsumsi jus buah naga merah (Hylocereus polyrhizus) dengan penambahan kulit buah naga merah sebanyak 20\% saja yang termasuk dalam kelompok perlakuan. Pada penelitian ini variabel pengganggu (confounding variable) berupa pencatatan asupan makan masih menggunakan metode food recall saja. Metode yang lebih baik adalah jika menggunakan gabungan antara metode food recall dan SQFFQ (Semi Quantitative Food Frequency Questionnaire). Atau akan lebih baik jika menggunakan metode food weighing. 


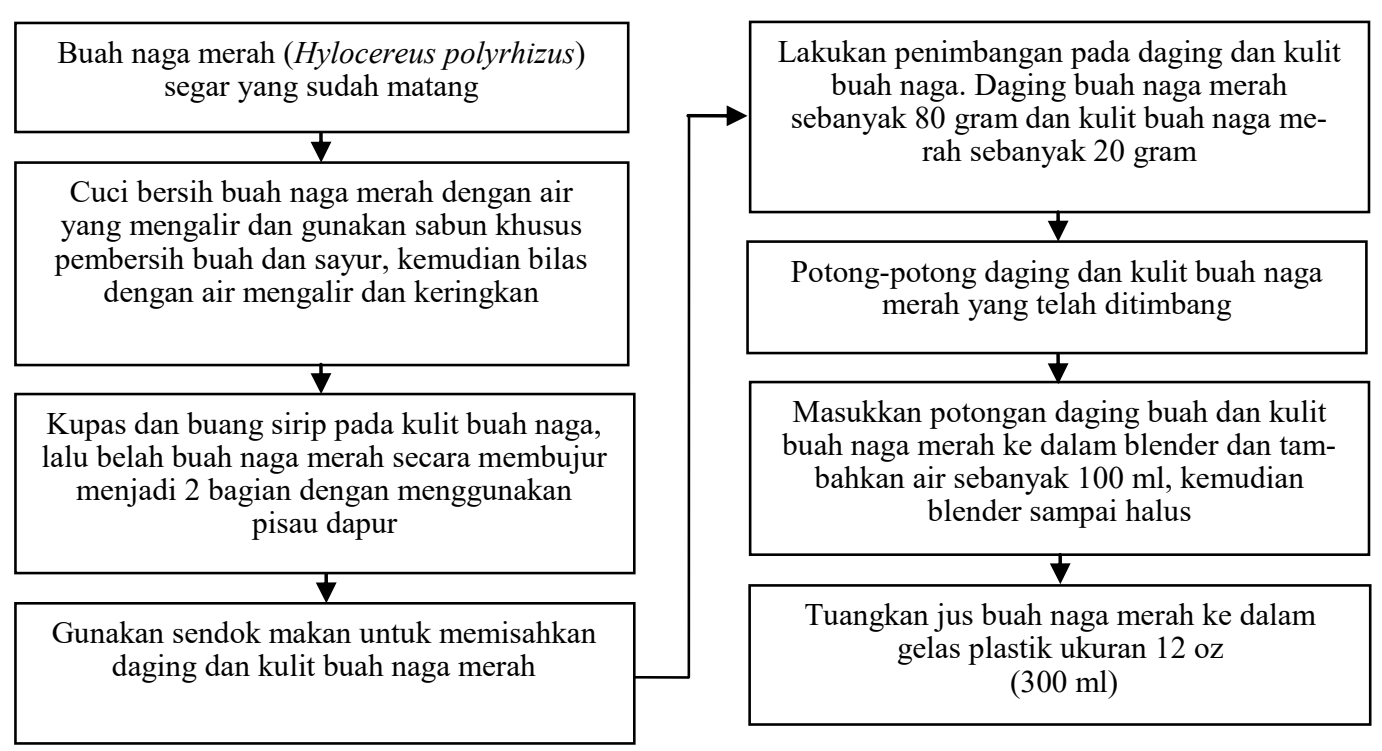

\section{Gambar 1. Prosedur Pembuatan Jus Buah Naga Merah (Hylocereus polyrhizus) dengan Penambahan Kulit Buah Naga Merah}

\section{HASIL}

Jumlah subjek dalam penelitian ini adalah sebanyak 36 orang. Subjek penelitian dibagi menjadi 2 kelompok, yaitu kelompok perlakuan dan kelompok kontrol. Karakteristik subjek penelitian berupa umur dan jenis kelamin.Berdasarkan hasil penelitian diketahui bahwa umur subjek penelitian yang paling banyak adalah pada kelompok umur 19-29 tahun, yaitu berjumlah 10 orang $(56 \%)$ pada kelompok perlakuan dan12 orang $(67 \%)$ pada kelompok kontrol. Jenis kelamin subjek penelitian pada kelompok perlakuan yang paling banyak adalah laki-laki, yaitu sebanyak 10 orang $(56 \%)$, sedangkan pada kelompok kontrol yang paling banyak adalah perempuan, yaitu sebanyak 13 orang $(72 \%)$.

Berdasarkan hasil uji beda, tidak ada perbedaan asupan lemak, kalium, kalsium, magnesium, vitamin c, natrium dan serat antara kedua kelompok $(p>0,05)$ (Tabel 1). Rata-rata hasil pengukuran tekanan darah pre test pada seluruh subjek penelitian adalah tekanan darah sistolik sebesar 116,25 $\pm 9,88$ dan tekanan darah diastolik sebesar 74,03 \pm 7,05 $\mathrm{mmHg}$ (Tabel 1). Berdasarkan hasil uji signifikansi Mann Whitney diketahui bahwa tidak terdapat perbedaan tekanan darah pre test sistolik $(p=0,050)$ dan diastolik $(p=0,188)$ pada kedua kelompok penelitian (Tabel 2$)$

Berdasarkan tabel 3 dan 4 dapat diketahui bahwa pada kelompok perlakuan rerata penurunan tekanan darah sistolik paling banyak terjadi pada hari ke-3, dan penurunan tekanan darah diastolikpaling banyak terjadi pada hari ke-2. Sedangkan pada kelompok kontrol,tidak terjadi perubahan pada ratarata tekanan darah post test pada hari pertama, terjadi peningkatan rata-rata tekanan darah sistolik maupun diastolik pada hari ke-2, dan terjadi penurunan ratarata tekanan darah sistolik maupun diastolik pada hari ke-3.

Berdasarkan tabel 5 dan 6 diketahui bahwa pada kelompok perlakuan terjadi penurunan rata-rata tekanan darah baik sistolik maupun diastolik.
Sedangkan pada kelompok kontrol terjadi peningkatan rata-rata tekanan darah sistolik, dan terjadi penurunan rata-rata tekanan darah diastolik

\section{PEMBAHASAN}

Faktor umur subjek penelitian perlu diperhatikan karena kejadian hipertensi cenderung meningkat seiring dengan pertambahan usia. Hasil penelitian menunjukkan bahwa umur subjek penelitian yang paling banyak adalah pada kelompok umur 19-29 tahun, yaitu berjumlah 10 orang (56\%) pada kelompok perlakuan dan berjumlah 12 orang (67\%) pada kelompok kontrol.

Umur merupakan faktor risiko hipertensi yang tidak dapat diubah. Dengan semakin meningkatnya umur seseorang, dinding pembuluh darah akan mulai kehilangan elastisitasnya. Perubahan struktur dan fungsi sistem pembuluh darah perifer ini menyebabkan perubahan tekanan darah, khususnya pada usia lanjut. Perubahan tersebut meliputi aterosklerosis, penurunan elastisitas jaringan ikat dan relaksasi otot polos pembuluh darah yang pada akhirnya mengakibatkan penurunan kemampuan distensi dan daya regang pembuluh darah sehingga kemampuan aorta dan arteri besar dalam mengakomodasi volume darah yang dipompa oleh jantung menurun, menyebabkan penurunan curah jantung dan peningkatan tahanan perifer sehingga terjadi peningkatan tekanan darah(Martiningsih, 2011). Tanpa disadari tubuh menghasilkan radikal bebas secara terus menerus, baik melalui metabolisme normal maupun dari lingkungan seperti polusi udara, ultraviolet, asap rokok, makanan (tinggi lemak, rendah serat) dan lainlain. Oleh karena itu, seiring dengan umur yang bertambah, maka bertambah pula penumpukan radikal bebas dalam tubuh hingga terjadi stres oksidatif dan peningkatan tekanan darah(Winarsih, 2013).

Hasil penelitian menunjukkan bahwa jenis kelamin subjek penelitian pada kelompok perlakuan yang paling banyak adalah laki-laki, yaitu sebanyak 10 orang $(56 \%)$. Sedangkan pada kelompok kontrol, 
Tabel 1

Rata-rata Asupan Lemak, Kalium, Kalsium, Magnesium, Vitamin C, Natrium dan Serat

\begin{tabular}{cccc}
\hline & $\begin{array}{c}\text { Kelompok Perlakuan }(\mathbf{n}=\mathbf{1 8}) \\
\text { Mean } \pm \text { SD }\end{array}$ & $\begin{array}{c}\text { Kelompok Kontrol }(\mathbf{n}=\mathbf{1 8}) \\
\text { Mean } \pm \text { SD }\end{array}$ & $\boldsymbol{P}$ \\
\hline Lemak (gr) & $41,98 \pm 16,40$ & $48,26 \pm 20,27$ & 0,314 \\
Kalium (mg) & $842,22 \pm 171,47$ & $972,52 \pm 304,20$ & 0,123 \\
Kalsium (mg) & $132,45 \pm 46,17$ & $138,67 \pm 70,47$ & 0,756 \\
Magnesium (mg) & $173,44 \pm 53,34$ & $163,06 \pm 43,07$ & 0,525 \\
Vitamin C (mg) & $23,81 \pm 2,12$ & $23,62 \pm 2,23$ & 0,692 \\
Natrium (mg) & $393,04 \pm 468,26$ & $379,02 \pm 368,27$ & 0,962 \\
Serat (gr) & $6,21 \pm 1,72$ & $6,06 \pm 2,80$ & 0,402 \\
\hline
\end{tabular}

Tabel 2

Rata-rata Tekanan Darah Pre Test Pada Kelompok Perlakuan dan Kelompok Kontrol

\begin{tabular}{|c|c|c|c|}
\hline & $\begin{array}{c}\text { Kelompok Perlakuan }(n=18) \\
\text { Mean } \pm \text { SD }\end{array}$ & $\begin{array}{c}\text { Kelompok Kontrol }(n=18) \\
\text { Mean } \pm \text { SD }\end{array}$ & $\boldsymbol{P}$ \\
\hline Sistolik & $119,72 \pm 6,05$ & $112,78 \pm 11,78$ & 0,050 \\
\hline Diastolik & $75,83 \pm 5,49$ & $72,22 \pm 8,08$ & 0,188 \\
\hline
\end{tabular}

diketahui bahwa jenis kelamin yang paling banyak adalah perempuan, yaitu sebanyak 13 orang $(72 \%)$. Jenis kelamin merupakan salah satu faktor yang mempengaruhi tekanan darah.Berdasarkan hasil penelitian Wahyuni dan Eksanoto (2013), perempuan cenderung menderita hipertensi daripada laki-laki. Pada penelitian tersebut sebanyak $27,5 \%$ perempuan mengalami hipertensi, sedangkan untuk laki-laki hanya sebesar 5,8\%(Wahyuni \& Eksanoto, 2013). Perempuan akan mengalami peningkatan resiko tekanan darah tinggi (hipertensi) setelah menopouse yaitu usia diatas 45 tahun. Perempuan yang belum menopouse dilindungi oleh hormon estrogen yang berperan dalam meningkatkan kadar High Density Lipoprotein (HDL). Kadar kolesterol HDL rendah dan tingginya kolesterol LDL (Low Density Lipoprotein) mempengaruhi terjadinya proses aterosklerosis dan mengakibatkan tekanan darah tinggi(Anggraini dkk, 2009). Asupan lemak, kalium, kalsium, magnesium, vitamin C, natrium dan serat diperoleh dari rata-rata asupan makan dan minum selama tiga hari dengan metode food recall 3x24 jam. Berdasarkan hasil uji beda, tidak ada perbedaan asupan lemak, kalium, kalsium, magnesium, vitamin $\mathrm{C}$, natrium dan serat antara kelompok perlakuan dan kelompok kontrol $(p>0,05)$. Hal ini menunjukkan bahwa kedua kelompok penelitian dalam kondisi yang homogen.

Berdasarkan hasil penelitian diketahui bahwa rata-rata tekanan darah sistolik dan diastolik pre test pada kelompok perlakuan adalah sebesar 119,72/75,83 mmHg, sedangkan pada kelompok kontrol adalah sebesar 112,78/72,22 mmHg. Rata-rata penurunan tekanan darah sistolik pada kelompok perlakuan yang paling banyak terjadi pada hari ke-3, dan penurunan tekanan darah diastolik pada kelompok perlakuan yang paling banyak terjadi pada hari ke-2. Sedangkan pada kelompok kontrol, dapat diketahui bahwa tidak terjadi perubahan pada rata-rata tekanan darah post test pada hari pertama jika dibandingkan dengan tekanan darah pre test. Pada kelompok kontrol terjadi peningkatan rata-rata tekanan darah sistolik maupun diastolik pada hari ke-2 penelitian, dan terjadi sedikit penurunan rata -rata tekanan darah sistolik maupun diastolik pada hari ke-3 jika dibandingkan dengan rata-rata tekanan darah sistolik dan diastolik pada hari ke-2 penelitian.Berdasarkan hasil pengukuran tekanan darah subjek penelitian, diketahui bahwa pada hari ke3 penelitian, kelompok perlakuan yang diberi jus buah naga merah mengalami penurunan tekanan darah sistolik dengan rata-rata sebesar $6,11 \mathrm{mmHg}$ dan penurunan tekanan darah diastolik dengan rata-rata sebesar 3,33 mmHg. Sedangkan kelompok kontrol yang tidak mendapatkan jus buah naga merah mengalami rata-rata peningkatan tekanan darah sistolik sebesar 2,77 $\mathrm{mmHg}$, dan mengalami penurunan tekanan darah diastolik dengan rata-rata sebesar $0,27 \mathrm{mmHg}$.

Hasil uji Mann Whitney terhadap data selisih tekanan darah sistolik antara kelompok perlakuan dan kelompok kontrol menunjukkan nilai Asymp. Sig. (2tailed) bernilai sama dengan 0,002 maka keputusannya adalah ada perbedaan yang signifikan pada selisih tekanan darah sistolik kelompok perlakuan dan kelompok kontrol. Sedangkan hasil uji Mann Whitney terhadap data selisih tekanan darah diastolik kelompok perlakuan dan kelompok kontrol menunjukkan bahwa nilai Asymp. Sig. (2-tailed) bernilai sama dengan 0,189 maka keputusannya adalah tidak ada perbedaan yang signifikan pada selisih tekanan darah diastolik kelompok perlakuan dan kelompok kontrol.Artinya, pemberian jus buah naga merah (Hylocereus polyrhizus) dengan penambahan kulit buah naga merah sebanyak 20\% efektif dalam menurunkan tekanan darah sistolik. Hasil ini sejalan dengan penelitian Grafika dimana hasil rerata tekanan darah sistolik sesudah minum jus buah naga merah sebesar $93 \mathrm{mmHg}$ lebih rendah dari sebelum minum jus buah naga merah sebesar 101 $\mathrm{mmHg}(\mathrm{p}<0,05)$. Sedangkan hasil rerata tekanan darah diastolik sesudah minum jus buah naga merah sebesar $67 \mathrm{mmHg}$ lebih rendah dari sebelum minum jus buah naga merah sebesar $70 \mathrm{mmHg}(\mathrm{p}<0,05)$ (Grafika, 
Tabel 3

Tabel Rata-rata Tekanan Darah Pre Test dan Post Test Harian Kelompok Perlakuan

\begin{tabular}{|c|c|c|c|}
\hline & & \multicolumn{2}{|c|}{ Kelompok Perlakuan } \\
\hline \multicolumn{2}{|c|}{ Waktu Pengukuran } & Sistolik & Diastolik \\
\hline Pre Test & & $119,72 \pm 6,05$ & $75,83 \pm 5,49$ \\
\hline \multirow[t]{3}{*}{ Post Test Hari ke- } & 1 & $116,67 \pm 7,67$ & $72,50 \pm 5,21$ \\
\hline & 2 & $114,44 \pm 7,04$ & $71,67 \pm 3,83$ \\
\hline & 3 & $113,61 \pm 8,36$ & $72,50 \pm 5,49$ \\
\hline
\end{tabular}

Tabel 4

Rata-rata Tekanan Darah Pre Test dan Post Test Harian Kelompok Kontrol

\begin{tabular}{|c|c|c|c|}
\hline & & \multicolumn{2}{|c|}{ Kelompok Kontrol } \\
\hline \multicolumn{2}{|c|}{ Waktu Pengukuran } & $\begin{array}{c}\text { Sistolik } \\
(\mathrm{mmHg}) \\
\text { Mean } \pm \text { SD } \\
\end{array}$ & $\begin{array}{c}\text { Diastolik } \\
(\mathbf{m m H g}) \\
\text { Mean } \pm \text { SD }\end{array}$ \\
\hline \multicolumn{2}{|l|}{ Pre Test } & $112,78 \pm 11,78$ & $72,22 \pm 8,08$ \\
\hline \multirow[t]{3}{*}{ Post Test Hari ke- } & 1 & $112,78 \pm 11,78$ & $72,22 \pm 8,08$ \\
\hline & 2 & $116,39 \pm 10,26$ & $72,78 \pm 5,74$ \\
\hline & 3 & $115,56 \pm 11,49$ & $71,94 \pm 7,10$ \\
\hline
\end{tabular}

2011).

Terapi farmakologi hipertensi diawali dengan pemakaian obat tunggal. Untuk pasien dengan tekanan darah 160/95 mmHg, rata-rata monoterapi menurunkan tekanan darah sistolik sekitar 7-13 mmHg dan diastolik sekitar 4-8 $\mathrm{mmHg}$. Sedangkan terapi kombinasi dari beberapa kelas obat ditunjukkan untuk menghasilkan pengurangan tekanan darah yang lebih besar daripada yang dihasilkan oleh monoterapi. Terapi kombinasi dengan efek hipotensif aditif akan memberikan pengurangan tekanan darah sekitar dua kali lebih besar daripada obat tunggal, yaitu sekitar 12$22 \mathrm{mmHg}$ untuk tekanan darah sistolik dan 7-14 $\mathrm{mmHg}$ untuk tekanan darah diastolik pada pasien dengan tekanan darah 160/95 mmHg(Boxtel, 2001). Pada penelitian ini, kelompok perlakuan yang diberi jus buah naga merah mengalami penurunan tekanan darah sistolik dengan rata-rata sebesar $6,11 \mathrm{mmHg}$ dan penurunan tekanan darah diastolik dengan rata-rata sebesar 3,33 $\mathrm{mmHg}$, sehingga jus buah naga merah dengan penambahan kulit buah naga merah sebanyak $20 \%$ dapat menjadi salah satu alternatif untuk membantu menurunkan tekanan darah.

Penurunan tekanan darah terjadi disebabkan vitamin $\mathrm{C}$ yang terkandung dalam daging buah naga merah sangat mencukupi kebutuhan perhari individu yaitu mencapai 540,27mg/100g(Norhayati, 2006). Vitamin $\mathrm{C}$ berperan dalam menurunkan tekanan darah karena vitamin $\mathrm{C}$ diduga memodulasi pengeluaran nitric oxide(Higdon, 2013). Nitrit oksid (NO) merupakan Endothel Derived Releasing Factor (EDRF) yang bersifat sebagai vasodilator(Sunarti,
2007). Buah naga merah juga mengandung kalium dan flavonoid yang tinggi sehingga dapat menurunkan tekanan darah ${ }^{4}$. Kandungan kalium (per 100 gram berat dapat dimakan) dalam buah naga merah adalah sebanyak 56,96 mg(Khalili, 2006).Penelitianpenelitian klinis memperlihatkan bahwa pemberian suplemen kalium dapat menurunkan tekanan darah dengan suplementasi diet kalium 60-120 mmol/hari dapat menurunkan tekanan darah sistolik dan diastolik 4,4 dan 2,5 $\mathrm{mmHg}$ pada penderita hipertensi dan 1,8 serta $1,0 \mathrm{mmHg}$ pada orang normal(Kusnul \& Munir, 2012).Selain zat gizi, buah naga merah juga mengandung fitokimia yang baik bagi tubuh, diantaranya flavonoid. Kandungan flavonoid pada daging buah naga merah sebanyak 7,21 $\pm 0,02 \mathrm{mg}$ CE/100 gram(Panjuantiningrum, 2009). Flavonoid bekerja sebagai Angiotensin Converting Enzym (ACE) inhibitor dengan menghambat pembentukan angiotensin II dari angiotensin I. Dengan berkurangnya jumlah angiotensin II, efek vasokontriksi dan sekresi aldosteron semakin berkurang untuk reabsorpsi natrium dan air. Akhirnya tekanan darah akan menurun(Anggraini \& dkk, 2009). Pada pasien hipertensi terjadi peningkatan stres oksidatif(Prat, 2007). Stres oksidatif adalah suatu kondisi dimana jumlah antioksidan lebih rendah dibandingkan radikal bebas(Granger, Alexander, Llinas, Bennett , \& Khalil , 2001).Penelitian ini menggunakan penambahan kulit buah naga merah sebanyak 20\%. Berdasarkan hasil penelitian Herawati et al., disebutkan bahwa di dalam kulit buah naga terdapat 
Tabel 5

Rata-rata Selisih Tekanan Darah Subjek Penelitian Kelompok Perlakuan

\begin{tabular}{|c|c|c|c|}
\hline \multirow{2}{*}{ Tekanan Darah } & \multicolumn{3}{|c|}{ Kelompok Perlakuan } \\
\hline & Pre Test (mmHg) & Post Test (mmHg) & Selisih (mmHg) \\
\hline $\begin{array}{l}\text { Sistolik } \\
\text { Diastolik }\end{array}$ & $\begin{array}{l}119,72 \pm 6,057 \\
75,83 \pm 5,491\end{array}$ & $\begin{array}{l}113,61 \pm 8,368 \\
72,50 \pm 5,491\end{array}$ & $\begin{array}{l}6,11 \pm 6,31 \\
3,33 \pm 4,53\end{array}$ \\
\hline \multicolumn{4}{|c|}{$\begin{array}{c}\text { Tabel } 6 \\
\text { Rata-rata Selisih Tekanan Darah Subjek Penelitian Kelompok Kontrol }\end{array}$} \\
\hline \multirow{2}{*}{ Tekanan Darah } & \multicolumn{3}{|c|}{ Kelompok Perlakuan } \\
\hline & Pre Test (mmHg) & Post Test (mmHg) & Selisih (mmHg) \\
\hline $\begin{array}{l}\text { Sistolik } \\
\text { Diastolik }\end{array}$ & $\begin{aligned} 112,78 & \pm 11,785 \\
72,22 & \pm 8,085\end{aligned}$ & $\begin{array}{r}115,56 \pm 11,490 \\
71,94 \pm 7,100 \\
\end{array}$ & $\begin{array}{l}-2,77 \pm 9,58 \\
0,27 \pm 9,46 \\
\end{array}$ \\
\hline
\end{tabular}

kandungan betasianin sebesar $186,90 \mathrm{mg} / 100 \mathrm{~g}$ berat kering dan aktivitas antioksidan sebesar 53,71 persen (Harawati, 2012). Selain itu, menurut Handayani, kulit buah naga juga dipercaya mengandung zat pentacyclic, triyepene, dan taraxast yang dapat melenturkan pembuluh darah(Handayani, 2014).Betasianin adalah pigmen alami yang berasal dari tanaman. Pigmen betasianin banyak digunakan sebagai pewarna alami dalam industri makanan. Selain relevansinya sebagai pewarna, betasianin juga memiliki manfaat penting dalam kesehatan manusia sebagai antioksidan, antikanker, anti-lipidemic dan antimikroba(Le Belle, Vaillant, \& Imbert, 2006). Betasianin adalah senyawa yang berfungsi sebagai antioksidan yang dapat menangkal radikal bebas(Kanner, Harel, \& Granit, 2001)

\section{KESIMPULAN}

Ada perbedaan yang signifikan pada selisih tekanan darah sistolik kelompok perlakuan dan kelompok kontrol, dan tidak ada perbedaan yang signifikan pada selisih tekanan darah diastolik kelompok perlakuan dan kelompok kontrol. Artinya, pemberian jus buah naga merah (Hylocereus polyrhizus) dengan penambahan kulit buah naga merah sebanyak $20 \%$ efektif dalam menurunkan tekanan darah sistolik

\section{DAFTAR PUSTAKA}

Anggraini, A., \& dkk. (2009). Faktor-Faktor yang Berhubungan dengan Kejadian Hipertensi pada Pasien yang Berobat di Poliklinik Dewasa Puskesmas Bangkinang Periode Januari sampai Juni 2008 . Dalam Laporan Penelitian . Riau: Fakultas Kesehatan Universitas Riau.

Boxtel, C. (2001). Drug Benefits and Risks: International Textbook of Clinical Pharmacology. 502.

Dinas Kesehatan Kabupaten Jember. (2015). Angka Kejadian Hipertensi di Kabupaten Jember Tahun 2015. Jember: Dinas Kesehatan Kabupaten Jember .

Grafika, S. (2011). Pengaruh Jus Buah Naga Merah
(Hylocereus polyrhizus) Terhadap Tekanan Darah Normal Pada Perempuan Dewasa. Dalam Karya Tulis Ilmiah. Bandung: Universitas Kristen Maranatha.

Granger, J., Alexander, B., Llinas, M., Bennett, W., \& Khalil , R. (2001). Pathophysiology of Hypertension During Preeclampsia Linking Placental Ischemia with Endothelial Disfunction. Retrieved Desember 13, 2017, from Research Report: http://hyper.ahajournals.org/ content $/ 38 / 3 / 718$.long

Handayani, S. (2014). Kandungan Kimia Beberapa Tanaman dan Kulit Buah Berwarna serta Manfaatnya Bagi Kesehatan. Dalam Laporan Penelitian. Yogyakarta: Universitas Negeri Yogyakarta.

Harawati, N. (2012). Pemberian Minuman Fungsional Berbasis Ekstrak Kulit Buah Naga Merah (Hylocereus polyrhizus), Rosela (Hibiscus sabdariffa L.) dan Buah Salam (Syzygium polyanthum wigh walp). Dalam Skripsi. Jember: Fakultas Teknologi Pertanian Universitas Jember.

Higdon, J. (2013). Vitamin C. Retrieved Januari 23, 2016, from Research Report: http:// lpi.oregonstate.edu/mic/vitamins/vitamin-C.

Kanner, J., Harel, S., \& Granit, R. (2001). Betalains a New Class of Dietary Cationized Antioxidants. Journal of Agriculture and Food Chemistry, 49, 5178-5185.https:// www.ncbi.nlm.nih.gov/pubmed/11714300. [December 13, 2017].

Kementerian Kesehatan RI. (2013). Riset Kesehatan Dasar . Jakarta: Badan Penelitian dan Pengembangan Kesehatan Indonesia Kementerian Kesehatan Republik Indonesia .

Khalili, d. (2006). Proximate Composition and Selected Mineral Determination in Organically Grown Red Pitaya (Hylocereus sp.). Dalam Research Report. Malaysia: Universitas Zainal Abidin.

Kumala, M. (2014). Peran Diet Dalam Pencegahan dan Terapi Hipertensi. Dalam Laporan 
Penelitian. Jakarta: Bagian Gizi Fakultas Kedokteran Universitas Tarumanegara.

Kusnul, Z., \& Munir, Z. (2012). Efek Pemberian Jus Mentimun Terhadap Penurunan Tekanan Darah. Dalam Laporan Penelitian. Jombang: Universitas Pesantren Tinggi Darul 'Ulum.

Le Belle, F., Vaillant, F., \& Imbert, E. (2006). Pitahaya (Hylocereus spp): A new fruit crop, a market with a future. Journal of Fruits, 61, 237250.https://www.cambridge.org/core/ services/aop-cambridgecore. [December 13, 2017].

Martiningsih. (2011). Analisis Faktor-Faktor Yang Berhubungan dengan Terjadinya Hipertensi Primer pada Pasien di Poliklinik Penyakit Dalam RSUD Bima Ditinjau Dari Perspektif Self-Care Orem. Dalam Tesis. Jakarta: Program Pascasarjana Universitas Indonesia.

Norhayati, A. (2006). Komposisi Kimia dan Aktivis Antioksidan Buah Pitaya Merah (Hylocereus Sp.) dan Kesan Atas Paras Glukosa dan Profil Llpid Tikus yang Diaruh Hiperglisemia. Retrieved Maret 22, 2016, from Thesis Master Sains: http://www.lib.upm.edu.my.

Panjuantiningrum, F. (2009). Pengaruh Pemberian Buah Naga Merah (Hylocereus polyrhizus) Terhadap Kadar Glukosa Darah Tikus Putih Yang Diinduksi Aloksan. Dalam Skripsi. Su- rakarta: Universitas Sebelas Maret.

Prat, H. (2007). Relationshipp between Oxidative Stress and Essential Hypertension. Dalam Research Report. Santiago, Chile: University of Chile.

Siswoyo, R. (2013). Tumpas Penyakit Dengan Buah dan Sayuran Warna Ungu. Yogyakarta: Sakti.

Sunarti, d. (2007). Hubungangan Antara Homosistein dan Nitrit Oksid Pada Hipertensi Esensial di Jawa Tengah Indonesia. Dalam Laporan Penelitian. Yogyakarta: Bagian Biokimia Fakultas Kedokteran Universitas Gajah Mada.

Wahyuni, \& Eksanoto, D. (2013). Hubungan Tingkat Pendidikan Jenis Kelamin dengan Kejadian Hipertensi di Kelurahan Jagalan di Wilayah Kerja Puskesmas Pucang Sawit Surakarta. Jurnal Ilmu Keperawatan Indonesia.

Winarsih, H. (2013). Deteksi Aging Pada Perempuan Berdasarkan Status Antioksidan. Dalam Laporan Penelitian. Jakarta: Fakultas Kedokteran dan Ilmu- Ilmu Kesehatan Jurusan Ilmu Gizi Universitas Soedirman 